\title{
UUTINEN: Professori Jarkko Saariselle AAG:n John Rooney -palkinto
}

Maantieteen alan suurin tieteellinen järjestö, American Association of Geographers (AAG), on myöntänyt Oulun yliopiston maantieteen professori Jarkko Saariselle vuoden 2020 John Rooney -palkinnon. Kyseinen palkinto myönnetään erinomaisesta työstä sovelletun matkailu-, virkistys- ja urheilumaantieteen tutkimusaloilla. Valintakomitean perusteluna Saarisen palkitsemiselle oli esimerkillinen kestävyyden ja yhteisöperusteisen luonnonvarahallinnan tutkimustoiminta matkailumaantieteen alalla.

Vuonna 2013 Saariselle myönnettiin AAG:n Roy Wolfe -palkinto matkailumaantieteen tutkimusalan tieteellisistä ansioista. 